\title{
Frejdigt kan en Kvinde opslå sin Ridderhjelm...
}

Tom Buk-Swienty: Løvinden. Karen Blixen i Afrika, Gyldendal, 2018.

Karen Blixen havde adskillige referencer til B.S. Ingemann i sit forfatterskab. Hun skriver et sted om sin tids kvinder, at "frejdigt kan en Kvinde opslå sin Ridderhjelm og vise verden, at hun ikke er en formummet Skælm" (fra visen om Holger Danske, 1837). Det er præcis en sådan frejdig og frygtløs kvinde, som Tom Buk-Swienty får fremmanet i sin seneste biografi om Dinesen-slægten.

Der er ikke fokus på Karen Blixen som forfatter, men derimod som en kvinde fra det bedre borgerskab, der begiver sig ud i verden, til Afrika, hvor hun bliver bestyrer af en kaffefarm i en alder af 29 år, for siden at vende tilbage til Danmark som 46-årig i 1931. Det er disse 17 år som er omdrejningspunktet i bogen, der er struktureret i fire store afsnit omkring hendes arbejde med farmen og The Karen Coffee Company. Biografiens omdrejningspunkt er nemlig kaffefarmens $\varnothing$ konomi og trivsel. Takket være litteraten Benedicte Rostbøll og historikeren Per Bojes forskning (der i øvrigt begge krediteres behørigt i bogen) er det nemlig nu kommet frem, at Karen Blixen på ingen måde havde fod under egen farm, men at det var hendes onkel, Aage Westenholtz, der postede penge i sin nieces afrikanske eventyr.

Karen træder i karakter, efter ægtemanden Bror Blixen, et skvat af en ægtemand, endegyldigt sættes fra bestillingen som direktør for farmen. Trods sin fornemme baggrund var Bror slet og ret tarveligt opdragen. En skørtejæger af rang, der ikke kunne finde ud af at drive farmen, drikfældig, ødsel med penge, samtidig med at han uophørligt tiggede onkel Aage om flere penge i de breve og telegrammer, han sendte hjem til Danmark. Endelig smittede han Karen med syfilis: Skal vi hive en stereotyp frem fra de store fortællingers bagkatalog, så indtager Bror helt klart førstepladsen som bad guy: Han er slet og ret et dumt svin. Dette er min og ikke forfatterens konklusioner. Det tjener Tom Buk-Swienty til ære, at han nøgternt fremlægger sin fortælling. Han dømmer ikke fortiden, men lægger den frem på dens egne præmisser. Det lyder muligvis gammeldags i en postmoderne tidsalder, men for et værk der vil gå den historiske biografis ærinde, er det et både nobelt og prisværdigt karaktertræk. For første gang, mener jeg, har vi fået et historisk tidsbillede af de verdener, som omgav Karen Blixen i idé-og mentalitetshistorisk forstand. Tiden op til, under og lige efter Første Verdenskrig er en utrolig sammensat tid i europæisk historie, hvor tradition og modernitet brydes frem og tilbage. Flere af personerne fremstår som fremsynede og reaktionære på én og samme tid. Elskeren og storvildtjægeren Denys Finch-Hatton begyndte som en af de første at argumentere imod de skånselsløse og overdrevne drab på Afrikas vilde dyr i en række indlæg i Times Magazine. Han foreslog progressive ideer om jagtlicens og begrænset jagt. Til gengæld mente han ikke, at kvinder burde få stemmeret.

Ligeså med Karen Blixen selv. Hendes sympati lå hos de indfødte, og hun gjorde mange gode ting for afrikanerne på hendes jorder. Buk-Swienty mener, at hun er en firstmover i forhold til at beskrive, hvordan sådanne 'naturfolk' var foran den europæiske civilisation på en lang række områder, herunder hendes opfattelse af 
dem, men det er et klassisk narrativ, vi kan spore tilbage til Jean Jacques Rousseau: B.S. Ingemann havde den præcis samme opfattelse, da han i 1842 skrev om grønlændere i romanen Kunnuk og Naja, hvor han, fuldstændig i tråd med Karen Blixens opfattelse af flere af de stammefolk hun er omgivet af, skriver om et oplyst folk, der er civiliseret på dets egne præmisser, ikke har brug for love, altid er glade og aldrig skændes - eller drikker alkohol! Selvom Blixen startede skole, infirmeri og sørgede for farmens indfødte i stort og småt, og uanset de bedste hensigter, var Karen Blixen lige så vel én af kolonisterne som de englændere, hun ikke brød sig om. At slå sine ansatte, som når hun giver husdrengene flade lussinger for mindre foreteelse, vidner om et voldsomt overherredømme, ligeledes eksemplet med englænderen Galbraith Cole, der skyder en sort mand, fordi han stjæler et får fra ham. Og frikendes for straf for: "Det var utænkeligt, at en søn af en lord ville blive straffet for at have dræbt en halvnøgen afrikaner" (268).

I den forstand er det ikke kønt, det tidsbillede, der manes frem af hvide kolonister i Britisk Østafrika (Kenya fra 1919). Også beskrivelsen af de uhyrlige massedrab på afrikanske dyr er ubærlig. Snart sagt på hver tredje side er europæere på safari og nedlægger elefanter, næsehorn, bøfler, giraffer og løver en masse. Tempoet, hvormed tyskere, englændere og franskmænd underlagde sig Afrika, "the scramble for Africa", er både eksemplet på en fremadstormende kolonialisme og en fremadstormende kapitalisme - de to går hånd i hånd. På mange måder synes Buk-Swientys fortælling om Karen Blixen at minde om historikeren Eric Hobsbawms bøger, The Age of Empire og The Age of Capital, blot koncentreret i en maggiterning, kogt ned i beskrivelsen af ét enkelt menneskeliv og de mennesker, hun omgav sig med. Store personligheder og historiske begivenheder blev en del af Karen Blixens afrikanske liv i kapitalismens og kolonialismens tidsalder. Da den engelske kronprins Edward besøgte Kenya i oktober 1928, som del af sin rundtur for The British Empire, gæstede han også Karen Blixens farm. Baronessen fik i løbet af ingen tid stablet en stor stammedans på benene til ære for ham. Kronprinsen er i øvrigt lige så depraveret beskrevet som resten af den adel der introduceres i bogen; ifølge kronprinsens egen sekretær, Tommy Lascelles, tænkte prinsen kun på "wine and women” under sit afrikanske besøg (585).

Karen Blixen var dannet, belæst, berejst og intellektuel. Ofte er hun portrætteret som den excentriske, snobbede, anoreksi- og syfilisramte forfatter, en stakkel, der i sidste time formåede at omsætte sin evne til at fortælle historier til et succesrigt forfatterskab. Buk-Swienty tager et opgør med denne kliché og tegner et billede af en driftig og entreprenant direktør, der ikke gik af vejen for hårdt fysisk arbejde på farmen, der rummede over 100 ansatte. Karen både spredte møg fra kvægfoldene, kørte traktor og læssede vogne med kaffesække. Det var også i disse år, at hendes kærlighedsforhold til Denys Finch Hatton blomstrede. Et afgørende moment mellem de to indtraf, da Denys kort og kontant rådede Karen til at få foretaget en abort: "Strongly advice cancel Daniels visit", som der står på den telegrambesked, der er gengivet på s. 528 (Daniel var kodeordet for et muligt barn mellem de to). Denys tabte derefter langsomt sin fortryllelse af Karen og kastede sin kærlighed på en anden kvinde, Beryl Markham, der som den første kvinde fløj over Atlanterhavet som pilot i 1936. En kvinde, som Karen Blixen af gode og forståelige grunde aldrig har nævnt i sit forfatterskab, heller ikke i Den afrikanske farm. 
I denne læsers øjne gør det en forskel i receptionen af Karen Blixen, både som forfatter og som menneske, at faktuelle oplysninger som disse lægges frem. At Denys så kort og kontant afviste et faderskab, når han vidste, hvor brændende Karen Blixen ønskede sig et barn, at han ikke gik ind for kvinders stemmeret - det bidrager alt sammen til et mere nuanceret og komplekst portræt af Denys Finch Hatton, hvor der ofte har været en tendens til, muligvis foranlediget af Karens egen tekster (og Robert Redfords portræt af ham i filmen "Out of Africa" fra 1985), at opfatte ham udelukkende som en charmerende engelsk Eton-uddannet gentleman, der reciterede Shakespeare og lyttede til Wagner. Charmerende gentleman, javist, men han var også så meget andet.

Løvinden er en rigtig god bog, hvorunder der ligger et kæmpe stort stykke historisk research. Også billedsiden er berigende, med flere hidtil ukendte billeder af Karen Blixen. Hun ser allermest glad ud på de billeder, hvor hun er på sin farm, omgivet af dyr, mennesker og kaffeplanter.

Titlen er velvalgt, fordi den symboliserer en kvinde der kæmpede det bedste hun havde lært for at holde sammen på sin farm og sit kærlighedsforhold. Bogen gjorde mig klogere og gav mig et nyt og mere positivt syn på Karen Blixen. Efter endt læsning var jeg ikke ét sekund i tvivl om, at Karen Blixen blev en fri og emanciperet kvinde i Afrika, da hun tog kaffefarmens overlevelse på sig. Karen Blixen "opslog sin ridderhjelm" i Afrika, skjulte sig ikke, men stod ved den hun var. Gamle Ingemann havde ret; der er forskel på det liv, vi lever i fordækthed, og det liv vi kan leve, når vi står ved dem, vi er.

Anmeldt af Lone Kølle Martinsen

\section{Den leende og legende Blixen}

Charlotte Engberg: Latter og lettere beruset. Om at læse Karen Blixen, Syddansk Univsersitetsforlag, 2019.

Karen Blixen efterlyste flere gange i sit liv legekammerater med sans for det, hun kaldte fun. Det uoversættelige ord var for hende forbundet med fandenivoldsk latter, intens livsfølelse, lidenskabeligt mod og dødsforagt, med humor, ironi, leg, munterhed og ikke mindst med indbildningskraft og fortællelyst eller med Goethes formulering Lust zu fabulieren. I litteraturforskeren Charlotte Engberg har Blixen omsider fundet en læser, der tager hendes begreb om fun alvorligt, ikke som nøgle til forståelse af hendes væsen, selv om det også kunne være muligt, men som et velegnet begreb til at indkredse en bestemt kvalitet ved Blixens fortællinger og ved selve hendes måde at konstruere en fortælling på. Og det er netop gennem opmærksomheden på latteren i Blixens tekster - og derudover også gennem en række øjenåbnende perspektiveringer til billedkunsten - at Engberg bringer nye indsigter frem i sin eminente udgivelse med den besnærende titel Latter og lettere beruset. Om at læse Karen Blixen. 